\title{
単結晶Ni基超合金CMSX-4のクリープ抵抗に及ぼす 単純時効および応力時効の影響
}

\author{
近藤 義宏*・北㠃 直弥*・行方 二郎*・大井 成人*2・服部 博*2 \\ Effects of Aging and Stress Aging on Creep Resistance of Single Crystal Ni-base Superalloy CMSX-4 \\ Yoshihiro Kondo, Naoya Kitazaki, Jirou NameKata, Narihito OHi and Hiroshi Hattori
}

Synopsis : Influence of the formation of rafted structure of $\gamma^{\prime}$ phase on creep resistance has been investigated using a single crystal nickel-base superalloy, CMSX-4. The rafted structure of $\gamma^{\prime}$ was controlled by conducting stress aging (creep test) at $1273 \mathrm{~K}-160 \mathrm{MPa}$ up to $3.24 \times 10^{6} \mathrm{~s}$. Aging without stress, called simple aging, was also performed at $1273 \mathrm{~K}$ up to $3.6 \times$ $10^{6} \mathrm{~s}$. Cuboidal $\gamma^{\prime}$ in the specimen as heat treated turned to the rafted one during a transient creep stage of stress aging. In the simple aging, cuboidal $\gamma^{\prime}$ became larger without changing their shape. The stress enhanced creep tests were conducted at $1273 \mathrm{~K}-250 \mathrm{MPa}$ to evaluate the creep resistance of the stress aged specimens and the simple aged ones. There was little difference in the minimum creep rate between the simple aged specimens and as heat treated one. But minimum creep rates of stress aged specimens were always larger than those of as heat treated one. The TEM observation of specimens interrupted the stress enhanced creep test at minimum creep rate showed that the stress aged specimens have the $\gamma$ region partially with high dislocation density which was not detected both in as heat treated specimen and the simple aged ones. The larger minimum creep rate in the stress aged specimens with rafted structure of $\gamma^{\prime}$ phase was caused by the increase in the width of the channel of $\gamma$ matrix.

Key words : creep ; superalloy ; single crystal ; $\gamma^{\prime}$ phase ; rafted structure.

\section{1. 緒言}

単結晶 $\mathrm{Ni}$ 基超合金は, $60 \%$ を超える非常に高い体積率の 強化相, $\gamma^{\prime}$ 相を有することによって優れたクリープ破断強 さおよびクリープ抵抗を示す。この種の合金を応力下にお いて加熱すると, 初期の立方体状の $\gamma^{\prime}$ 相は互いに連なって ラフト構造を形成する。ラフト構造の成長方向は応力軸に 垂直であるとされてきた122)。

また， $\gamma^{\prime}$ 相がラフト構造を形成すると，転位の上昇運動 が抑制され，立方体状のものに比べクリープ抵抗は増加す ると考えられてきだ)4。事実, Pearson らは単結晶の Ni1.3at\%Al-9at\%Mo-2at\%Ta 合金に, 1311K, 207MPa, $5.4 \times 10^{4} \mathrm{~s}$ の応力時効を行い, 未使用材とのクリープ抵抗の 比較を, $1172 \mathrm{~K}, 414 \mathrm{MPa}$ のクリープ試験を行うことによっ て調べた。その結果, 応力時効材のクリープ速度は未使用 材に比べ小さいことを明らかにしている3)。ところが, Nathal らは単結晶の NASAIR $100 に, 1273 \mathrm{~K}, 148 \mathrm{MPa}, 1.5 \times 10^{5} \mathrm{~S}$ の応力時効を施し, 未使用材とのクリープ抵抗の比較を, $1033 \mathrm{~K}$ のクリープ試験により検討している。その結果, Pearson ら の結果とは逆に応力時効材の最小クリープ速度が，未使用 材に比べ約 2 倍大きくなることを明らかにした5)。こ相反
する実験結果が生じた原因としては，1）応力時効において， $\gamma^{\prime}$ 相がラフト構造をいまだ形成していなかったこと，2）応 力時効中に共晶 $\gamma^{\prime}$ 相の形態変化が生じたこと,および 3 ) 応 力時効とクリープ試験との温度差によって, $\gamma^{\prime}$ 相が再析出し, 析出形態が変化したことが考えられる。すなわち，1)につ いては, 両者の応力時効条件が 1 水準のみであり, $\gamma^{\prime}$ 相が ラフト構造に至った証拠を提示していないことに問題があ る。確かに, Pearson らは, $1311 \mathrm{~K}, 207 \mathrm{MPa}$ の応力時効に おいて $1.62 \times 10^{6} \mathrm{~S}$ を経過すると $\gamma^{\prime}$ 相がラフト構造に達して いることを提示した。しかし，時効時間が $1 / 30$ に相当する $5.4 \times 10^{4} \mathrm{~s} に お い て ラ フ ト$ 構造が形成していることを確かめ てはいない。また，2）については，Nathalらが実験に供し た NASAIR 100においては共晶 $\gamma^{\prime}$ 相の存在が無視できな い。すなわち, 粗大な共晶 $\gamma^{\prime}$ 相の存在は応力時効中に共晶 $\gamma^{\prime}$ 相近傍の $\gamma^{\prime}$ 相のラフト化を妨げる可能性がある。さらに, 3 ) については, クリープ試験 と応力時効との温度差, $\Delta \mathrm{T}$, がいずれの研究においても $100 \mathrm{~K}$ 以上大きく, とくに Nathal らの研究における $\Delta \mathrm{T}$ は Pearson らの研究での值に比べさ らに100K大きい。クリープ抵抗を評価するための試験温度 を必要以上に低下させることは，応力レベルを著しく高め て, 転位が $\gamma^{\prime}$ 相を Cutting する条件下でクリープ抵抗の評 
価を行う可能性を高める。これらの問題点を取り除いて, クリープ抵抗に及ぼす $\gamma^{\prime}$ 相のラフト化の影響を議論するに は, 応力時効すなわち, クリープ試験において種々の時間 で試験を停止し， $\gamma^{\prime}$ 相のラフト化を確かめ, それらを定量 化することがまず重要である。また，共晶 $\gamma^{\prime}$ 相が残存しな い合金老供試材として採用すること,クリープ停止試験(応 力時効） と応力時効材のクリープ抵抗を調べるためのクリ ープ試験との温度差を小さくすることが必要であろう。

そこで本研究では, 溶体化処理によって, 共晶 $\gamma^{\prime}$ 相が消 失する単結晶 $\mathrm{Ni}$ 基超合金 $\mathrm{CMSX}-4$ を用い, クリープ停止 試験 (以後, $1273 \mathrm{~K}, 160 \mathrm{MPa}$ の応力時効と呼ぶ) $1.08 \times$ $10^{5} \sim 3.24 \times 10^{6} \mathrm{~S}$ の範囲で行い, $\gamma^{\prime}$ 相のラフト化について定 量的なデータを得る。一方, 応力時効と同一温度の $1273 \mathrm{~K} の$ 単純時効を $3.60 \times 10^{5} \sim 3.60 \times 10^{6} \mathrm{~S}$ の範囲で行う。これら応 力時効材および単純時効材について, 同一温度, $1273 \mathrm{~K}, の$ 応力を高めた短時間クリープ試験を行い, クリープ抵抗に 及ぼす $\gamma^{\prime}$ 相のラフト化の効果を明らかにする。

\section{2. 供試材および実験方法}

供試合金として, 単結晶 $\mathrm{Ni}$ 基超合金である $\mathrm{CMSX}^{-4}$ を 用いた。その化学組成をTable 1 に示す。精密鋳造により, 長さ方向を $[001]$ とした $13 \mathrm{~mm}$ 丸棒の単結晶に 8 段階の溶 体化処理 ${ }^{\dagger}$ おび 2 段階の時効処理 ${ }^{\dagger}$ を施した。これを以後, 末使用材 (As heat treated) と呼ぶ。この未使用材から平 行部径 $8 \mathrm{~mm}$, 標点距離 $50 \mathrm{~mm}$ の応力時効用クリープ試験片 を作製した。応力時効は引張方位を $[001]$ とて，1273K， $160 \mathrm{MPa}$ にて行った。なお，160MPaにおける推定クリープ 破断時間は $3.60 \times 10^{6} \mathrm{~S} て ゙ あ る 。 1.08 \times 10^{5} \sim 3.24 \times 10^{6} \mathrm{~S}$ まで の 7 水準の時間で試験を停止し,これを応力時効材とした。 また比較材として, 未使用材に $1273 \mathrm{~K} て ゙$ 最長 $3.60 \times 10^{6} \mathrm{~s}$ の時 効を施し, これを単純時効材とした。高応力クリープ試験 は, 未使用材, 応力時効材および単純時効材より作製した 平行部径 $6 \mathrm{~mm}$, 標点距離 $30 \mathrm{~mm}$ のつば付き試験片を用い, 引張方位を [001］として, $1273 \mathrm{~K}, 250 \mathrm{MPa} に て$ に行った。 また，クリープ速度が最小となる時点で負荷のまま冷却し て, 試験を停止したクリープ停止材も準備した。

組織観察は，X線ラウエ透過法により決定した（100）に ついて，SEMおよびTEMを用いて行った。 $\gamma^{\prime}$ 相の体積率

Table 1. Chemical composition of a single crystal nickel-base superalloy, CMSX-4, investigated $(w t \%)$

\begin{tabular}{c|c|c|c|c|c|c|c|c|c}
\hline $\mathrm{Cr}$ & $\mathrm{Co}$ & $\mathrm{Al}$ & $\mathrm{Ti}$ & $\mathrm{Mo}$ & $\mathrm{Ta}$ & $\mathrm{W}$ & $\mathrm{Re}$ & $\mathrm{Hf}$ & $\mathrm{Ni}$ \\
\hline 6.4 & 9.3 & 5.5 & 0.9 & 6.3 & 6.2 & 6.2 & 2.8 & 0.1 & Bal. \\
\hline
\end{tabular}

$\dagger$ 溶体化処理条件 : $1550 \mathrm{~K} \times 7.2 \times 10^{3} \mathrm{~s} \rightarrow 1561 \mathrm{~K} \times 7.2 \times 10^{3} \mathrm{~s} \rightarrow 1569 \mathrm{~K} \times$ $1.08 \times 10^{4} \mathrm{~s} \rightarrow 1577 \mathrm{~K} \times 1.08 \times 10^{4} \mathrm{~s} \rightarrow 1586 \mathrm{~K} \times 7.2 \times 10^{3} \mathrm{~s} \rightarrow 1589 \mathrm{~K} \times 7.2$ $\times 10^{3} \mathrm{~s} \rightarrow 1591 \mathrm{~K} \times 7.2 \times 10^{3} \mathrm{~s} \rightarrow 1594 \mathrm{~K} \times 7.2 \times 10^{3} \mathrm{~S} \rightarrow$ Gas fan cool † 2 時効処理条件 : $1413 \mathrm{~K} \times 2.16 \times 10^{4} \mathrm{~s} \rightarrow 1144 \mathrm{~K} \times 7.2 \times 10^{4} \mathrm{~s} \rightarrow$ Air cool
は画像解析装置を用い, 測定面積に占める $\gamma^{\prime}$ 相の面積率よ り求めた。また， $\gamma^{\prime}$ 相のアスペクト比は線分析法により, 応力軸に対し垂直および平行方向における $\gamma^{\prime}$ 相の平均幅の 比から算出した。なお， $\gamma^{\prime}$ 相の体積率およびアスペクト比 の測定は各試料とも $2000 \mu \mathrm{m}^{2}$ 以上の面積にわたって行った。

\section{3. 実験結果}

\section{$3 \cdot 1$ 供試材の組織}

供試材の走査電子顕微鏡組織を Fig. 1 亿示す。共晶 $\gamma^{\prime}$ 相 は認められず,立方体状の $\gamma^{\prime}$ 相が規則的に析出している。 また， $\gamma^{\prime}$ 相の一片は約 $0.5 \mu \mathrm{m} に よ く$ 調整されている。

\section{$3 \cdot 2$ クリープ停止試験}

応力時効条件である $1273 \mathrm{~K}, 160 \mathrm{MPa}$ における未使用材の クリープ速度一時間曲線をFig. 2 に示す。なお, 応力時効材 の時効時間を困中に矢印で示した。 $1.08 \times 10^{6} \mathrm{~S} て ゙$ 最小クリ 一プ速度を示しており，応力時効材の時効時間は遷移域の 後半から破断直前にまでわたっている。

\section{$3 \cdot 3$ 応力時効材および単純時効材の組織}

$1.08 \times 10^{6}$ おむ゙ $3.60 \times 10^{6} \mathrm{~S}$ 単純時効材の走查電子顕微鏡 組織をFig. 3 に示す。 $1.08 \times 10^{6} \mathrm{~s}$ 単純時効材 (Fig. $3-(\mathrm{a})$ ) では $\gamma^{\prime}$ 相はわずかに粗大化しているが，立方体状のものは それぞれ独立している。一方， $3.60 \times 10^{6} \mathrm{~S}$ 単純時効材 (Fig.

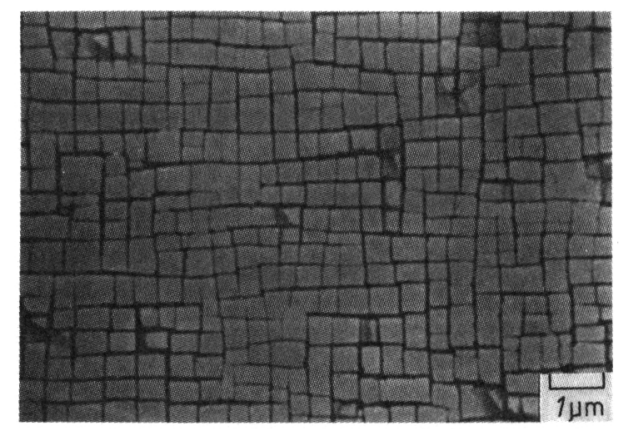

Fig. 1. Scanning electron micrograph of a single crystal nickel-base superalloy, CMSX -4 .

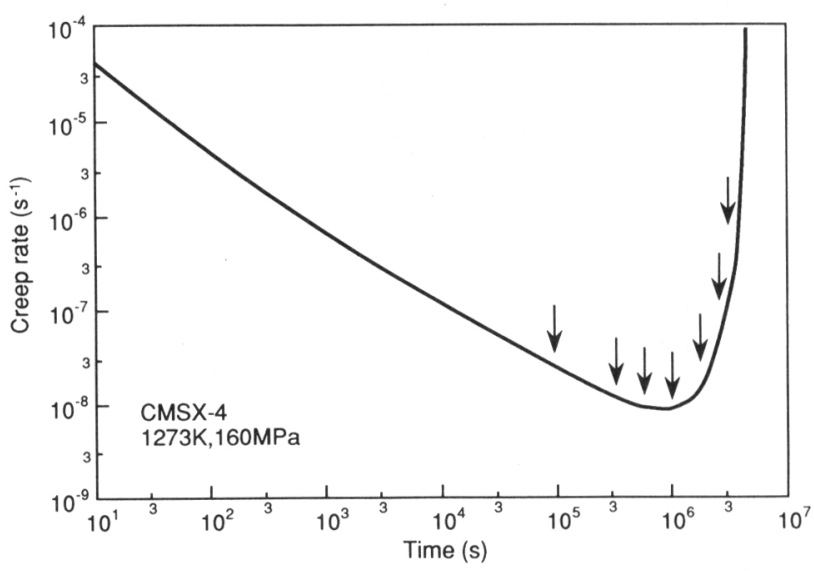

Fig. 2. Creep rate-time curve of the specimen crept at $1273 \mathrm{~K}-160 \mathrm{MPa}$. The arrows mean stress aging time. 

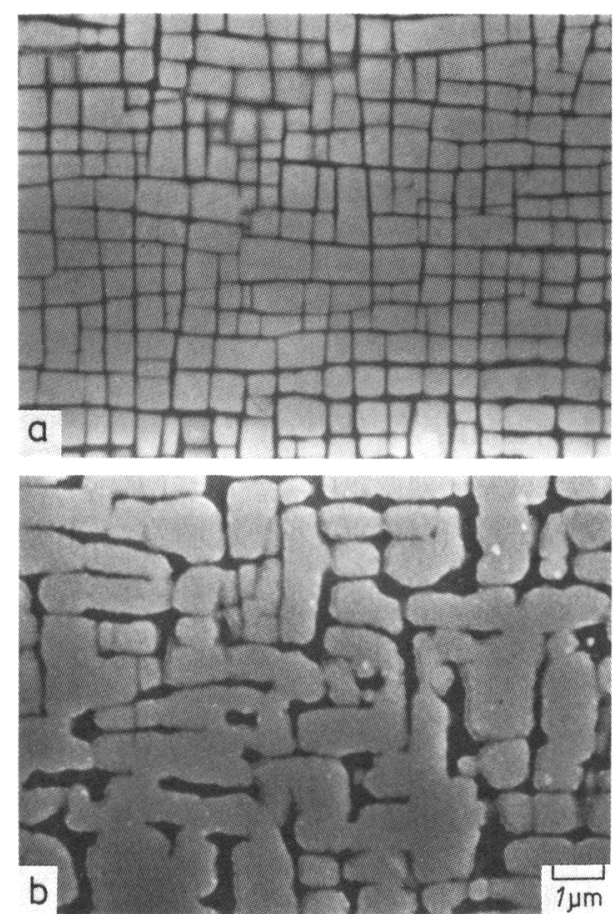

Fig. 3. Scanning electron micrographs of the specimens simple - aged at $1273 \mathrm{~K}$ for (a) $1.08 \times 10^{6} \mathrm{~s}$ and (b) $3.60 \times 10^{6} \mathrm{~s}$.
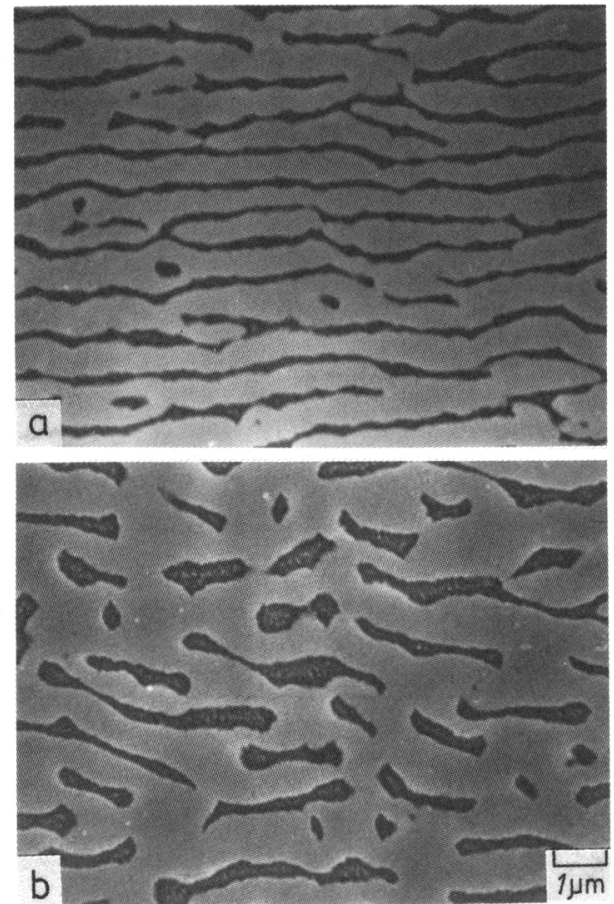

Fig. 4. Scanning electron micrographs of the specimens stress-aged at $1273 \mathrm{~K}-160 \mathrm{MPa}$ for (a) $1.08 \times 10^{6} \mathrm{~s}$ and (b) $3.24 \times 10^{6} \mathrm{~s}$. Stress axis is vertical in these photos.

3-(b))では $\gamma^{\prime}$ 相は著しく粗大化し, 写真の上下, 左右方向 に連結している。

$1.08 \times 10^{6}$ およ゙ $3.24 \times 10^{6} \mathrm{~S}$ 応力時効材の走查電子顕微鏡 組織をFig. 4 に示す。 $1.08 \times 10^{6} \mathrm{~s}$ 応力時効材 (Fig. 4 -(a)) では $\gamma^{\prime}$ 相は応力軸に対して垂直方向に連結し,ラフト構造
を形成する。しかし， $3.24 \times 10^{6} \mathrm{~s}$ 応力時効材 (Fig. 4 -(b)) では $\gamma^{\prime}$ 相はさらに粗大化して,ラフト構造は崩れ, 母相であ る $\gamma$ 相は $\gamma^{\prime}$ 相により分断され，孤立する。このように， $\gamma^{\prime}$ 相の形態は応力負荷によって大きく変化する。

\section{$3 \cdot 4$ 時効に伴う組織変化の定量化}

\section{$3 \cdot 4 \cdot 1$ 体積率}

単純時効材および応力時効材における $\gamma^{\prime}$ 相の体積率の時 効時間の増加に伴う変化をFig. 5 に示す。 $\gamma^{\prime}$ 相の体積率は応 力の有無によらず，また，時効時間の長短によらず， $76 \%$ とほほ一定值を示す。このことから， $\gamma^{\prime}$ 相の析出は時効前 の熱処理によりほほぼ完了したとみなせる。

$3 \cdot 4 \cdot 2$ アスペクト比

両時効材における $\gamma^{\prime}$ 相のアスペクト比の時効時間の経過 に伴う変化をFig. 6 に示す。 $\gamma^{\prime}$ 相のアスペクト比は単純時 効索施しても, ほとんど変化せず，未使用材と同じ約 1 で あった。一方，応力時効を施すと， $\gamma^{\prime}$ 相のアスペクト比は $1.08 \times 10^{5} \mathrm{~s}$ の時効までは約 1 であるが, $3.60 \times 10^{5} \mathrm{~s}$ の時効に よってほぼ 3 にまで増加し, $1.08 \times 10^{6} \mathrm{~s} て ゙$ 最大值約 7 走す。 しかし，時効時間が $1.80 \times 10^{6} \mathrm{~S}$ を超えると， $\gamma^{\prime}$ 相のアスペ

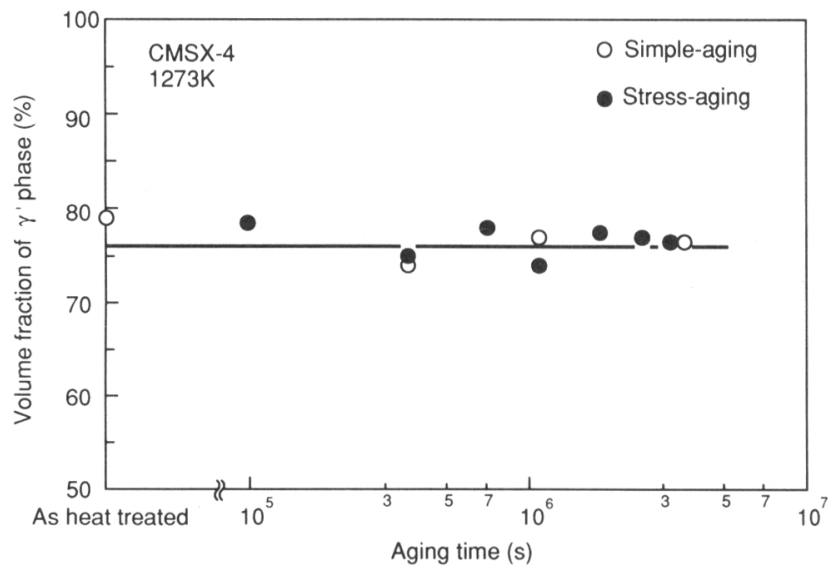

Fig. 5. Changes in the volume fraction of $\gamma^{\prime}$ of the simple-aged and stress-aged specimens with aging time at $1273 \mathrm{~K}$.

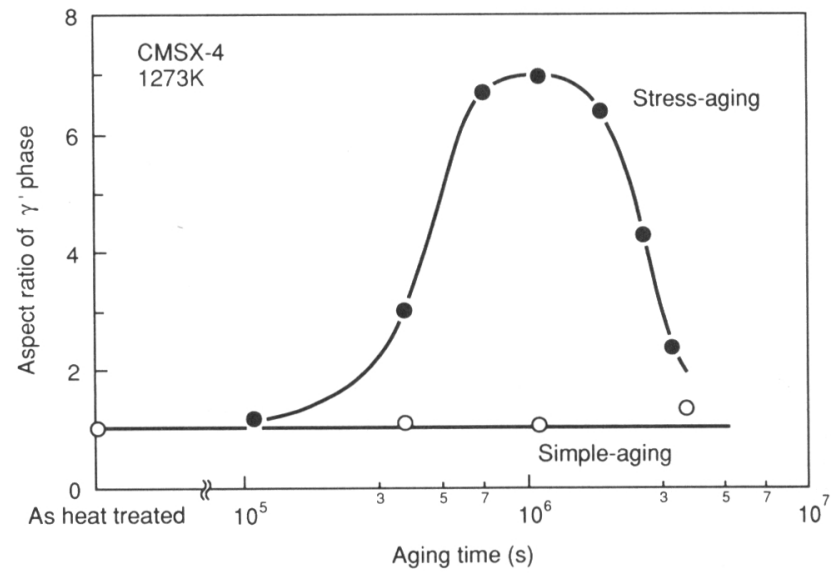

Fig. 6. Changes in the aspect ratio of $\gamma^{\prime}$ of the simple-aged and stress-aged specimens with aging time at $1273 \mathrm{~K}$. 
クト比は減少し， $3.24 \times 10^{6} \mathrm{~s} て ゙ は$ 約 2 にまで低下する。こ のことから $\gamma^{\prime}$ 相のアスペクト比が最も大きなラフト構造は最 小クリープ速度を示す時点で形成しているが，このラフト 構造は安定ではなく，加速域においてはクリープ速度の増 加に伴って，崩れていることが明らかとなった。

\section{$3 \cdot 5$ 高応カクリープ試験結果}

$3 \cdot 5 \cdot 1$ クリープ破断特性.

単純時効材および応力時効材の $1273 \mathrm{~K}, 250 \mathrm{MPa}$ におり 破断時間と時効時間との関係を Fig. 7 に示す。 $3.60 \times 10^{5}$ $\sim 3.60 \times 10^{6} \mathrm{~S}$ の単純時効を施しても破断時間は未使用材と ほぼ同じである。一方，応力時効材においては，時効時間 の長いものほど, $1273 \mathrm{~K}, 250 \mathrm{MPa}$ におる破断時間は減少

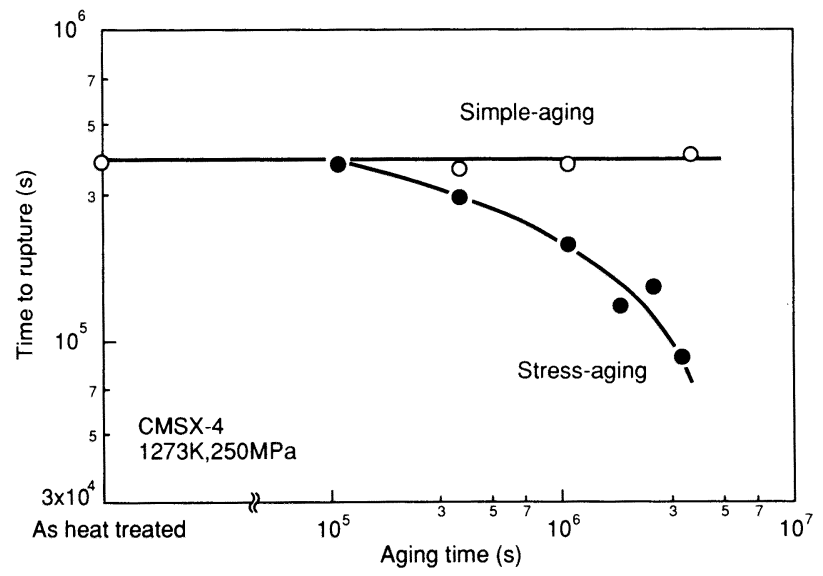

Fig. 7. Changes in time to rupture at $1273 \mathrm{~K}-$ $250 \mathrm{MPa}$ of the specimens as heat treated, simple-aged and stress-aged with aging time.

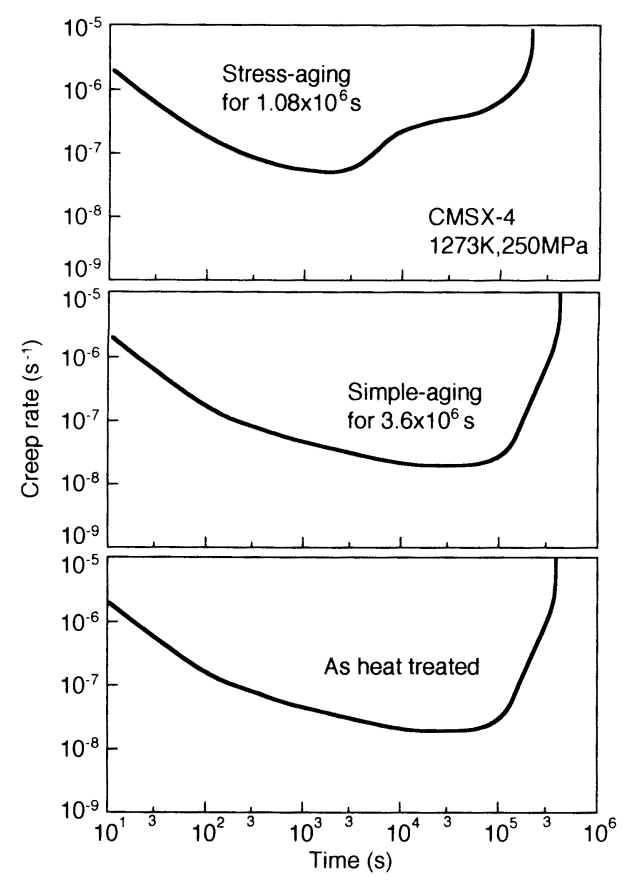

Fig. 8. Creep rate-time curves at $1273 \mathrm{~K}-250 \mathrm{MPa}$ of the specimens as heat treated, simple-aged for $3.60 \times 10^{6} \mathrm{~s}$ and stress-aged for $1.08 \times 10^{6} \mathrm{~s}$.

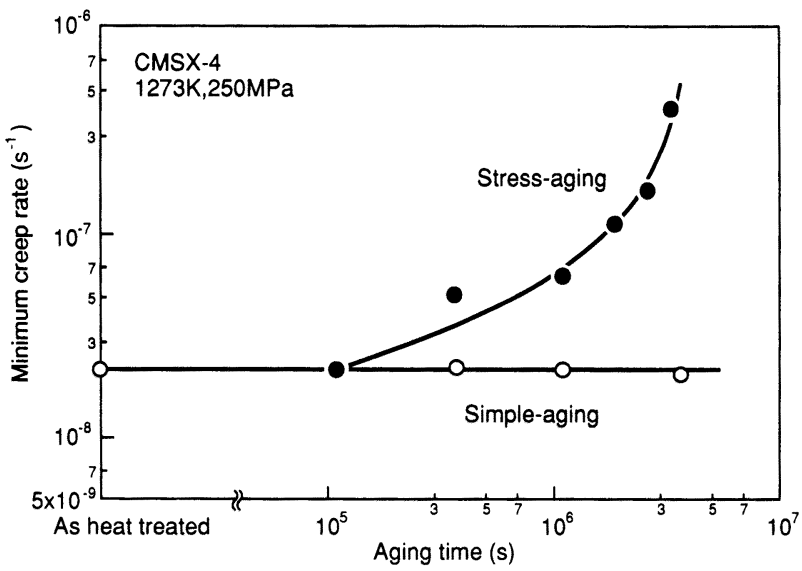

Fig. 9. Changes in minimum creep rate at $1273 \mathrm{~K}-$ $250 \mathrm{MPa}$ of the specimens as heat treated, simple-aged and stress-aged with aging time.

する。すなわち， $\gamma^{\prime}$ 相のラフト構造が形成される $7.2 \times 10^{5}$ $\sim 1.8 \times 10^{6} \mathrm{~S}$ 応力時効によって破断時間は未使用材の $1 / 2 \sim 1 / 3$ に減少し，ラフト構造が崩れる $3.24 \times 10^{6} \mathrm{~s}$ 応力時 効で破断時間は未使用材の約 $1 / 5$ になる。

$3 \cdot 5 \cdot 2$ 最小クリープ速度

$1273 \mathrm{~K}, 250 \mathrm{MPa}$ におりる未使用材, $3.60 \times 10^{6} \mathrm{~S}$ 単純時効 材および $1.08 \times 10^{6} \mathrm{~S}$ 応力時効材のクリープ速度一時間曲線 をFig. 8 に示す。 $3.60 \times 10^{6} \mathrm{~s}$ 単純時効材の最小クリープ速度

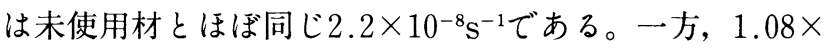
$10^{6} \mathrm{~s}$ 応力時効材の最小クリープ速度は未使用材の約 3 倍大 きな值を示す。

単純時効材および応力時効材の $1273 \mathrm{~K}, 250 \mathrm{MPa} に お け$ 最小クリープ速度の変化を時効時間に対しプロットし, Fig. 9 に示す。Fig. 3 に示すように, $3.6 \times 10^{6} \mathrm{~S}$ で顕著な $\gamma^{\prime}$ 相の 粗大化が生じていたにもかかわらず，単純時効材の最小ク リープ速度は時効時間にかかわらず一定で，未使用材とほ ぼ同じ值を示す。一方, 応力時効材の最小クリープ速度は 時効時間の増加に伴い増加する。すなわち, $\gamma^{\prime}$ 相のラフト構 造が形成される $7.2 \times 10^{5} \sim 1.8 \times 10^{6} \mathrm{~s}$ 応力時効材では未 使用材の $3 \sim 5$ 倍となり, ラフト構造が崩れる $3.24 \times 10^{6} \mathrm{~S}$ 応力 時効材では未使用材の約20倍となる。このように, CMSX-4 に単純時効を施してもクリープ抵抗はほとんど変化しない が，応力時効を施すとクリープ抵抗は大きく減少する。

\section{4. 考察}

前節において, CMSX-4 に単純時効を施すと $\gamma^{\prime}$ 相は粗大 化し，等方的に連結して塊状になるが，クリープ抵抗はほ とんど変化しないこと, 一方, 応力時効を施すと $\gamma^{\prime}$ 相はラ フト化し,さらに長時間側では $\gamma^{\prime}$ 相のラフト構造が崩れ, クリープ抵抗は単調に低下することを示した。そこで本節 では, 応力時効によってクリープ抵抗が低下した理由を検 討する。 
通常，多結晶合金の高温クリープによる強度低下は，粒 界における割れの発生および伝播のような機械的損傷と関

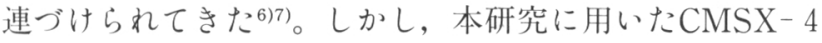
は単結晶合金であり，また応力時効後，試料表面層を深さ $1 \mathrm{~mm}$ 機械加工により除去している。このようにした応力時 効材の高応力クリープ試験における破断伸びは時効時間に 依存せず，いずれも約 $25 \%$ であった。これらのことから， 応力時効によるクリープ抵抗の低下が機械的損傷, すなわ ち試料断面積の減少あるいは割れや空泡の発生によるとは 考え難い。

また，多結晶合金の高温クリープに伴う強度低下が，機 械的損傷によらず,炭化物の凝集粗大化あるいはの相などの TCP相の析出による材料それ自体の変形抵抗の低下，すな

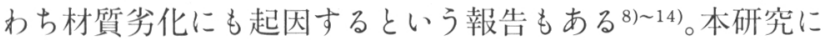
おける応力時効材でのクリープ抵抗の低下も試料全体で均 一に生じる組織変化に基づく材質劣化に起因するとも考光 られる。

単純時効材においてはクリープ抵抗の低下がほとんど生 じていなかったことから，単に $\gamma^{\prime}$ 相の等方的な粗大化のみ ではクリープ抵抗の低下は生じない。応力が加わることに よって生じたクリープ抵抗の低下は， $\gamma^{\prime}$ 相のラフト化とそ の構造が崩れることによるものと考えられる。そこで高応 力クリープ試験を行った未使用材，単純時効材および応力

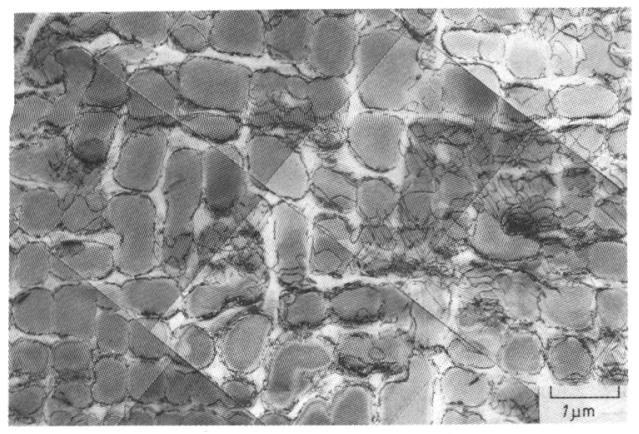

Fig. 10. Transmission electron micrograph of the specimen as heat treated and crept up to minimum creep rate at $1273 \mathrm{~K}-250 \mathrm{MPa}$.

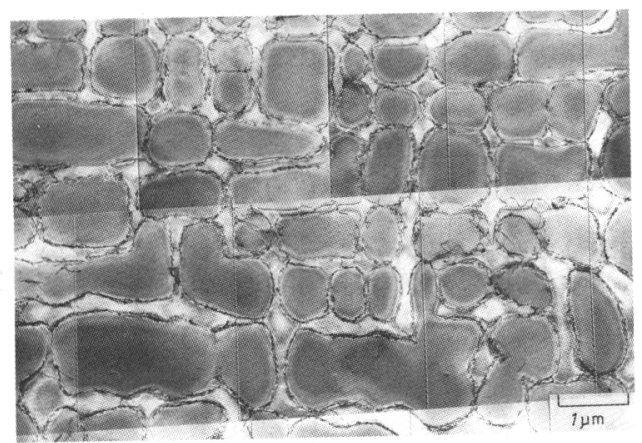

Fig. 11. Transmission electron micrograph of the specimen simple-aged for $3.6 \times 10^{6} \mathrm{~s}$ and crept up to minimum creep rate at $1273 \mathrm{~K}^{-}$ $250 \mathrm{MPa}$
時効材のクリープ停止材について転位下部組織観察を行っ た。

1273K, 250MPaにおいて最小クリープ速度を示す時点で 試験を停止した未使用材の透過電子顕微鏡組織を Fig.10に 示す。転位は $\gamma / \gamma^{\prime}$ 界面の $\gamma$ 母相側に集積しており， $\gamma^{\prime}$ 相中 ではほとんど観察されない。

未使用材とクリープ抵抗がほぼ同じであった $3.60 \times 10^{6} \mathrm{~S}$ 単 純時効したクリープ停止材の透過電子顕微鏡組織をFig.11に 示す。未使用材と同様, 転位は $\gamma / \gamma^{\prime}$ 界面の $\gamma$ 母相側に集積 し， $\gamma^{\prime}$ 相中では転位はほとんど観察されない。

未使用材の約 5 倍大きな最小クリープ速度走した $1.08 \times$ $10^{6} \mathrm{~s}$ 応力時効したクリープ停止材の透過電子顕微鏡組織を Fig.12に示す。未使用材抢よび3. $60 \times 10^{6} \mathrm{~S}$ 単純時効材とは異 なって, $\gamma$ 母相にはコントラストの異なる領域が局部的に認 められ，このコントラストの異なる領域では転位密度が高 い。また $\gamma / \gamma^{\prime}$ 界面における転位の数も多い。

最小クリープ速度が未使用材の約20倍にまで増加した $3.24 \times 10^{6} \mathrm{~S}$ 応力時効材のクリープ停止材の透過電子顕微鏡 組織をFig.13に示す。Fig.12で観察された $\gamma$ 母相のコントラ ストの異なる, 転位密度の高い領域がより多く認められる ようになる。そして，そのような領域における $\gamma^{\prime}$ 相に挟ま れた $\gamma$ 素地の幅はかなり増大している。また, $\gamma^{\prime}$ 相中に存在

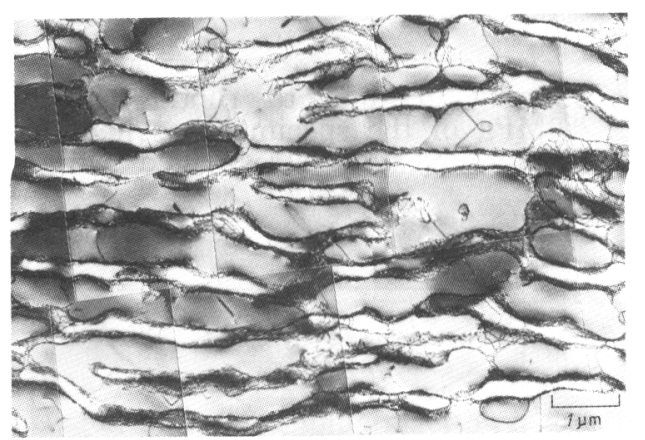

Fig. 12. Transmission electron micrograph of the specimen stress-aged for $1.08 \times 10^{6} \mathrm{~S}$ and crept up to minimum creep rate at $1273 \mathrm{~K}^{-}$ $250 \mathrm{MPa}$.

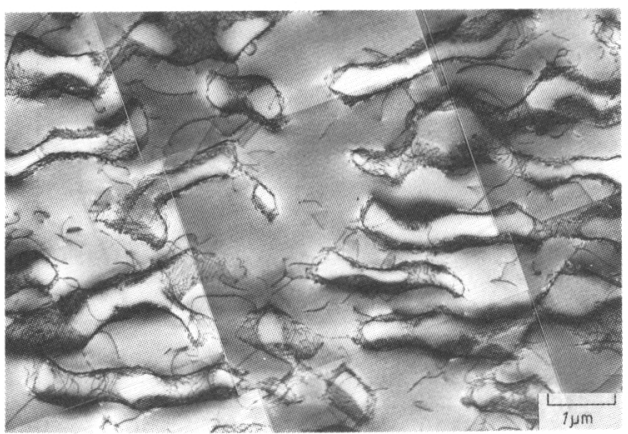

Fig. 13. Transmission electron micrograph of the specimen stress-aged for $3.24 \times 10^{6} \mathrm{~S}$ and crept up to minimum creep rate at $1273 \mathrm{~K}^{-}$ $250 \mathrm{MPa}$. 
すると思われる転位が観察されるようになる。このように， 未使用材に対する転位下部組織の変化は，単純時効材に比 べ応力時効材で大きい。

ところで, Dysonらは $\gamma^{\prime}$ 相の体積率が高い $\mathrm{Ni}$ 基超合金に おいて，加速クリープ領域でのクリープひずみに伴うクリ 一プ速度の増加は, 可動転位密度の増加に起因することを 示唆した15)。本研究でも,クリープ抵抗が低下した応力時効 材において, $\gamma$ 母相中に転位密度の高い領域か形成され, $\gamma / \gamma^{\prime}$ 界面における転位の数も多い。これらが可動転位密度の増 加と断定することはできないが, 現象的にはDysonらと同様 の結果が得られた。Dysonらはクリープの律速過程を転位の すべり運動とみなしているため，可動転位の数の増加がク リープ抵抗の低下を招くという解釈は論理的矛盾はない。 しかし， $\gamma^{\prime}$ 相は転位によってCuttingされていないこと，遷 移クリープが明確に観察されるなど，本研究における試験 条件でのクリープの律速過程は転位の上昇運動とみなせる。 したがって，加速クリープ域におけるクリープ抵抗の增加 はラフト構造の崩壊に伴って $\gamma^{\prime}$ 相間の $\gamma$ 素地の幅が局部的に 拡大して,大きなクリープ変形を招いたためと考えられる。 $\gamma$ 素地中の転位密度が高いのは， $\gamma / \gamma^{\prime}$ 界面転位が開放され たことによると推論した。また，アスペクト比が約 7 の応 力時効材のクリープ抵抗が単純時効材に比べ小さいのは, 応力無負荷での時効においては $\gamma^{\prime}$ 相間の $\gamma$ 素地の幅はほとん ぞ変化していないのに対し，応力負荷は $\gamma$ 素地の拡大を局部 的に起こす確率を高めたことによると推論した。これらの 結果より, $\gamma^{\prime}$ 相の体積率が70\%を超えるCMSX-4における $\gamma^{\prime}$ 相のラフト化はクリープ強化として働くことはなく，む しろクリープ弱化として働くものと結論される。

\section{5. 結論}

本研究では，単結晶 $\mathrm{Ni}$ 基超合金, CMSX-4 を用い,クリ ープ試験を種々の時間で停止し， $\gamma^{\prime}$ 相のラフト化の程度を 定量的に求めるとともに, これら応力時効材について応力 を高めたクリープ試験を行い，クリープ抵抗を評価した。 同様の検討を単純時効についても行い，両者の比較検討に よって $\gamma^{\prime}$ 相のラフト化がクリープ抵抗を高めるのか否かを 検討して，以下の結論を得た。

1) CMSX-4 に単純時効を施す $\boldsymbol{~}, \gamma^{\prime}$ 相は等方的に凝集 して塊状になる。しかし，応力時効を施すと $\gamma^{\prime}$ 相は応力軸 に対し垂直方向に凝集して，ラフト構造を形成するが，さ
らに長時間の時効を施すとラフト構造は崩れる。

2 ) $\gamma^{\prime}$ 相の体積率は時効条件および時効時間に依存せずほ ぼ一定である。また $\gamma^{\prime}$ 相のアスペクト比は単純時効材では 時效時間に依存せずほぼ一定であるが，応力時効材では時 効時間に伴い増加し, 最大值 7 を示した後, 約 2 にまで低 下寸る。

3 ) CMSX-4に単純時効を施してもクリープ破断時間は ほとんど変化しないが，応力時効を施すとクリープ破断時 間は単調に減少する。

4 ) CMSX-4 に単純時効を施しても, 高応力クリープ試 験における最小クリープ速度はほとんど変化しないが，応 力時効を施すと, 高応力クリープ試験における最小クリー プ速度は長時間時効材ほぼ増加する。

5 ) 高応力クリープ試験において最小クリープ速度を示し た時点で試験を停止した試料の転位下部組織観察より, 未 使用材および単純時効材においては転位は $\gamma / \gamma^{\prime}$ 界面の $\gamma$ 素 地側に存在し，転位網を形成するが， $\gamma^{\prime}$ 相中にはほとんぞ 観察されない。一方, 応力時効材では時効時間の経過に伴 い転位は $\gamma / \gamma^{\prime}$ 界面だけでなく， $\gamma$ 素地全体にわたって転位 密度の高い領域が認められるようになり，そのような $\gamma$ 素地 では $\gamma^{\prime}$ 相間の $\gamma$ 相の幅が拡大している。

6 ) 以上の結果より，高温クリープ中に生ずる $\gamma^{\prime}$ 相のラフ 卜化はクリープ強化としては㗢かず，むしろクリープ弱化 として働くものと結論される。

\section{文献}

1) J.K.Tien and R.P.Gamble: Met. Trans. A, 3 (1972), p.2157

2 ) M.V.Nathal and L.J.Ebert: Met. Trans. A, 16 (1985), p.427

3 ) D.D.Pearson, F.D.Lemkey and B.H.Kear: Proc. of the 4th Int'l Conf. Superalloys 1980, (1980), p.513

4 ) R.A.MacKay and L.J.Ebert: Met. Trans. A, 16 (1985), p.1969

5 ) M.V.Nathal, R.A.MacKay and R.V.Miner : Met. Trans. A, 20 (1989), p.133

6 ) D.A.Woodford: J.Eng. Mater. Technol., 101 (1979), p.311

7 ) N.Shin-ya and S.R.Keown : Mater. Sci., 13 (1979), p.89

8 ) K.R.Williams and B.Wilshire: Mater. Sci. Eng., 28 (1977), p. 289

9 ) K.R.Williams and B.J.Cane : Mater. Sci. Eng., 38 (1979), p.199

10) C.J.Bolton, B.F.Dyson and K.R.Williams : Mater. Sci. Eng., 46 (1980), p.231

11) L.P.Stoter: J.Mater. Sci., 16 (1981), p.1039

12) R.A.Stevens and P.E.J.Flewitt: Mater. Sci. Eng., 37 (1979), p. 237

13) J.M.Leitnaker and J.Bentley : Met. Trans. A, 8 (1977), p.1605

14) J.H.Hoke and F.Eberle: Trans. ASME, 79 (1957), p.307

15) B.F.Dyson and M.McLean: Acta Metall., 31 (1983), p.17 